\title{
Kennedy Channel and its geophysical lineaments: new evidence that the Wegener Fault is a myth
}

\author{
Thorkild M. Rasmussen and Peter R. Dawes
}

2010, the year under review, marks the centennial of perhaps the most controversial structure in the Arctic: the Wegener Fault, the $1000-\mathrm{km}$ long fracture that is supposed to underlie Nares Strait and define the north-western margin of an independent Greenland plate (Fig. 1). The seaway between Greenland and Ellesmere Island, Canada, was branded a megashear by Frank Taylor who, purely on physiographic expression, postulated massive Tertiary strike-slip (Taylor 1910). This revolutionary idea fittingly found a place in Alfred Wegener's theory of continental drift and thereafter in plate-tectonic theory with Greenland drifting hundreds of kilometres from North America along what Tuzo Wilson subsequently dubbed the 'Wegener Fault' (Wilson 1963).

Today, the concept lives on. In modern palaeogeography, Nares Strait is given a long multiphase dynamic history with collision of Greenland and Canada in the Palaeogene (Fig. 1). A freely drifting Greenland plate unconstrained by ties to North America is now part of conventional wisdom as related in textbooks, review articles and educational material available on the internet. Accordingly, the Wegener Fault is a standard feature in international compilations of world geology (e.g. UNESCO 2010; Fig. 2).

Unfortunately, this 100-year acclamation from Taylor (1910) to UNESCO (2010) is fundamentally flawed: the rocks and their relationships at Nares Strait flatly contradict the existence of the structure.

\section{Scope and aim of this paper}

This paper's four-page limit prevents discussion of the pros and cons of the Wegener Fault. For this, we refer to two multi-author volumes (Dawes \& Kerr 1982; Tessensohn $e t$ al. 2006) and to the latest papers (e.g. Hansen et al. 2011; Pulvertaft \& Dawes 2011). Our aim is twofold: (1) to mark the centennial of a lithospheric structure disputed by the onsite geology, and (2) to add new evidence in the form of magnetic field variations across northern Nares Strait (Kennedy Channel) that define a lineament in harmony with previous interpretations of gravity data.

\section{Regional setting}

The most recent overview of Nares Strait geology is by Harrison et al. (2006). Bedrock provinces of five ages are common to Greenland and Canada (Fig. 2).

In the south, Archaean-Paleoproterozoic crystalline shield is overlain by deposits of two sedimentary basins: the Mesoproterozoic Thule Basin that straddles northern Baffin Bay and Smith Sound, and the E-W-trending Palaeozoic Franklinian Basin that stretches westwards across northern Canada into Alaska. The Cambrian-Devonian fill of this basin is characterised by north-westerly thickening into a deep-water trough while its shelf overlaps the Thule Basin at Smith Sound. Neoproterozoic basic dykes cut the shield

The 100-year myth: Greenland as an independent drifting plate (1910-2010)
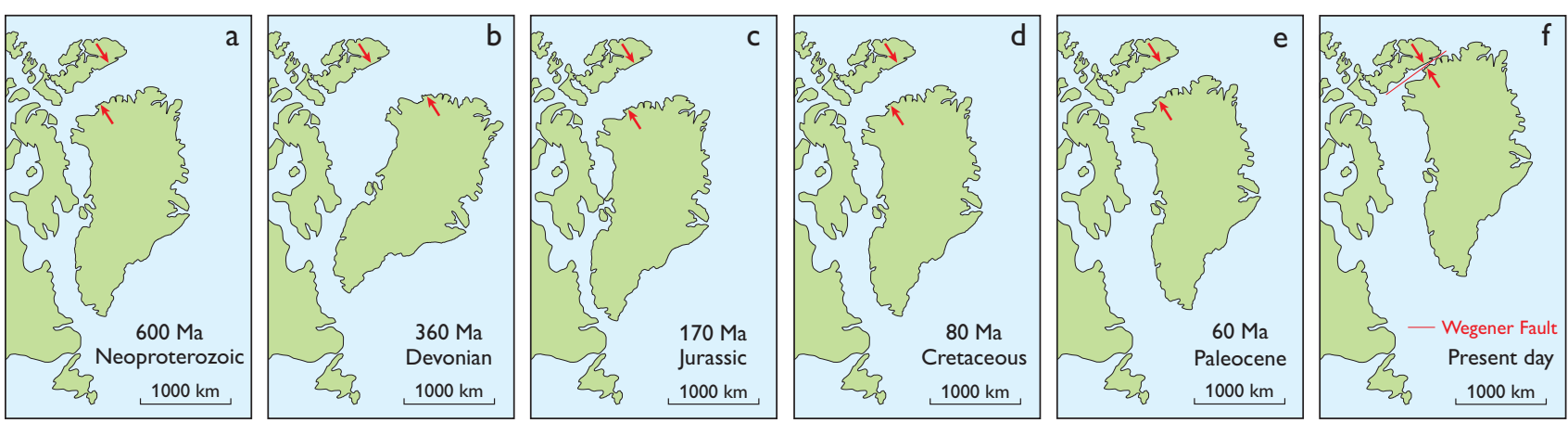

Fig. 1. Modern palaeogeography showing Greenland as a wandering plate detached from Canada throughout Phanerozoic time: (a) Cocks \& Torsvik (2006), (b-e) Torsvik et al. in Eide (2002), (f) present-day with the Wegener Fault (after Taylor 1910; UNESCO 2010). Red arrows mark the coast locations of magnetic and gravimetric anomalies described in this paper. 


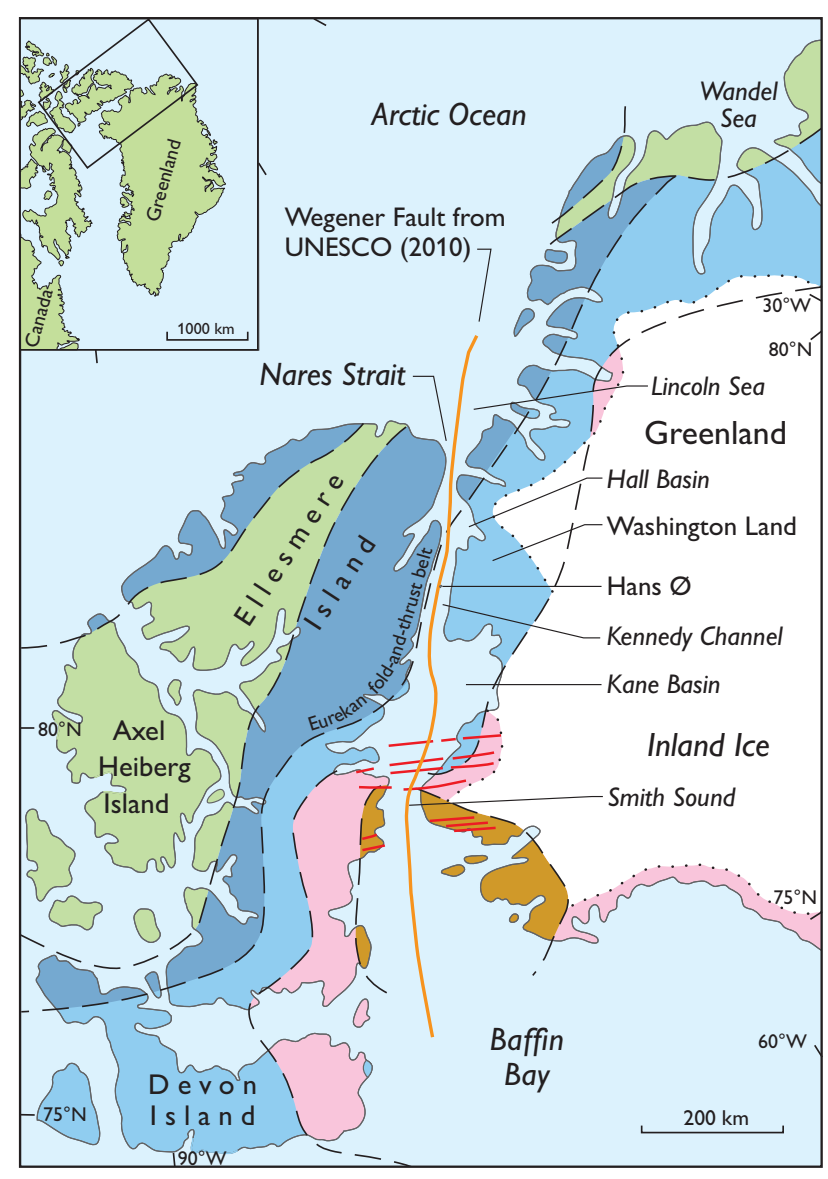

$\square$ Carboniferous-Cenozoic Sverdrup and Wandel Sea Basins

$\square$ Folded trough $\neg$ Cambrian-Devonian

$\square$ Arctic platform - Franklinian Basin

E Neoproterozoic basic dyke swarm

Mesoproterozoic Thule Basin

Archaean-Palaeoproterozoic shield

Fig. 2. Simplified geological map of the Nares Strait region. Note that a submarine Wegener Fault, such as UNESCO (2010), must bypass obstacles like those across Smith Sound and Kennedy Channel (see Fig. 4).

and its Mesoproterozoic cover but are eroded off at the subCambrian (Franklinian) unconformity. One E-W-trending basic dyke swarm has been mapped across southern Kane Basin and Smith Sound (Fig. 2; Oakey \& Damaske 2006). In end-Devonian time, Ellesmerian deformation transformed the Franklinian trough into a fold belt flanked on the south by the homoclinal Arctic platform. The fifth province - the Carboniferous-Cenozoic Sverdrup Basin - developed across the eroded, folded Franklinian rocks but overlapped onto the platform. In Palaeogene time, Eurekan tectonism deformed the Sverdrup Basin and underlying Franklinian rocks into a composite structural belt (Innuitian orogen).

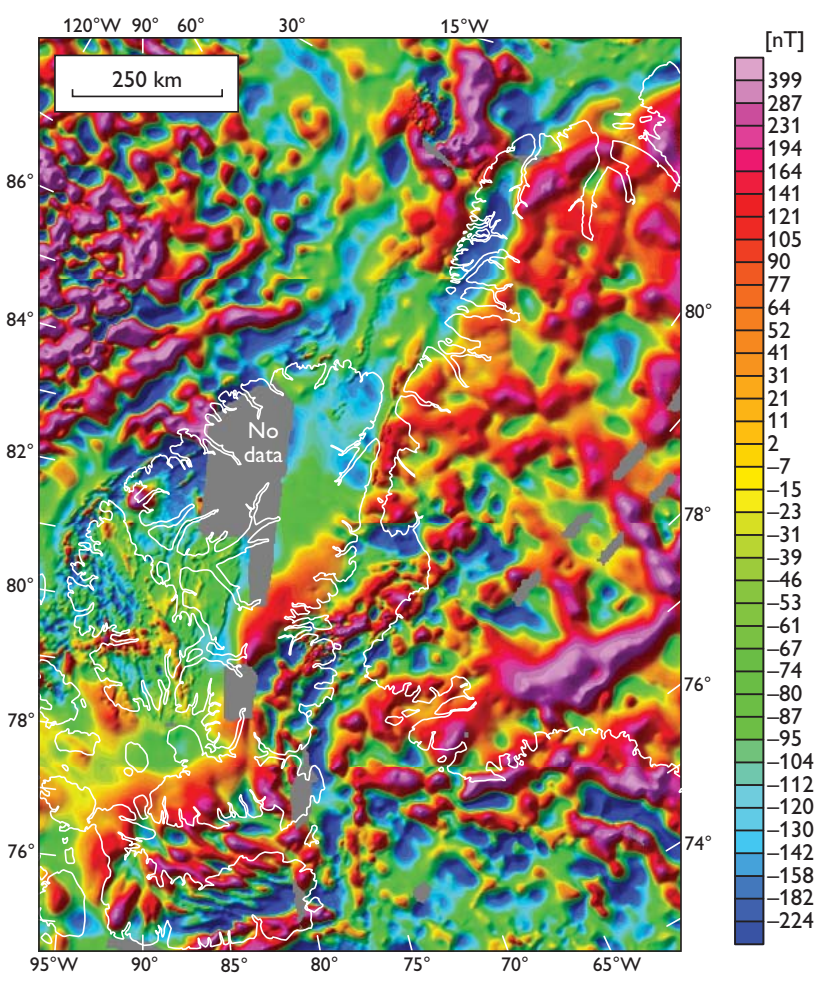

Fig. 3. Regional, total magnetic intensity showing the same region as Figs 2 and 4. Reproduced from Gaina et al. (2010).

\section{Geological relations at Kennedy Channel}

Kennedy Channel is sited within the Franklinian Basin with homoclinal strata of the Arctic platform to the southeast and the folded trough to the north-west. Nares Strait trends roughly NNE and thus oblique to the Franklinian Basin (Fig. 2). However, the southern boundary of the folded trough has a sinuous form so that at Kennedy Channel structures roughly follow the coast, while to the south they swing westwards inland and to the north at Hall Basin, eastwards across Greenland. Limits of Ellesmerian and Eurekan diastrophism near the seaway roughly coincide producing a complicated fold-and-thrust belt of Palaeozoic rocks with fault-bound packets of Cretaceous-Palaeogene deposits on Ellesmere Island (Mayr 2008).

Homoclinal Ordovician and Silurian strata dipping 1-3 ${ }^{\circ}$ to the north-west underlie Kennedy Channel and these are involved in the Eurekan fold-and-trust belt (Harrison et al. 2007). In Greenland, the Cambro-Silurian sedimentary pile overlying the shield is up to $3500 \mathrm{~m}$ thick and all evidence suggests that this geology continues offshore without structural break, with mid-channel Hans $\varnothing$ and other islands exposing the uppermost reefal part of the Silurian section (Dawes 2004). We stress that the latest maps portray a homoclinal Palaeozoic cover offshore unaffected by faulting (Harrison et al. 2007). This contrasts with the thesis of some, for 
example, Jackson et al. (2006, fig. 15), who draw a sinistral strike-slip fault just west of Hans $\varnothing$, a dislocation that "is hypothesized to be the leading edge of the plate boundary between the North American and Greenland plates" (Jackson et al. 2006, p. 21). Its location in Kennedy Channel is roughly as shown in UNESCO (2010; Fig. 2).

\section{The magnetic field anomalies}

Our analysis is based on recently compiled magnetic and gravimetric data over the Arctic (Gaina et al. 2009; Fig. 3). Included are high-resolution data acquired by a CanadianGerman project that in 2001 used a helicopter from an icebreaker to survey Kennedy Channel (Damaske \& Oakey 2006) and data acquired in 2003 by the Geological Survey of Canada (Oakey \& Damaske 2006). The data are low-pass filtered and levelled to provide a regional magnetic field representation of uniform spatial resolution.

Basically, a magnetic anomaly may be viewed as representing the response from a single isolated structure or the superimposed responses from several structures that merge into a well-defined anomaly. Which approach is applicable is mainly controlled by distance between observation level and the structures, and by the cut-off wavelength in any applied lowpass filtering. Our evaluation of continuity of anomalies is based on a tilt angle (Miller \& Singh 1994) representation of a $5 \mathrm{~km}$ upward-continued version of the magnetic field. The upward continuation puts emphasis on structures having a regional extent but has the drawback of merging responses from adjacent structures. Responses from shallow isolated structures are attenuated. The tilt angle provides structural information that is independent or unbiased with respect to magnetisation intensity of the structures.

Our focus here is on magnetic anomalies that can be linked to the crustal scale of Kennedy Channel close to the above-mentioned hypothetical plate boundary of Jackson $e t$ al. (2006). Relevant features are marked in Fig. 4: a trend line based on peak values for the tilt angle and a previously published trend line of the Nares Strait Gravity Low (NSGL; Oakey \& Stephenson 2008). We note that the magnetic trend line parallels the gravity trend for more than $1000 \mathrm{~km}$ along what is essentially the platform margin of the Franklinian Basin. This margin marks a drastic change in basin architecture from shallow shelf to deep trough with downwards flexuring of the substratrum or surface of the shield. The magnetic trend line is interrupted at Kennedy Channel but extrapolation along line provides an excellent match between the extended sections. The yellow dashed line crossing Lincoln Sea in Fig. 4 represents merged responses from diverse unconnected magnetic structures seen both onshore

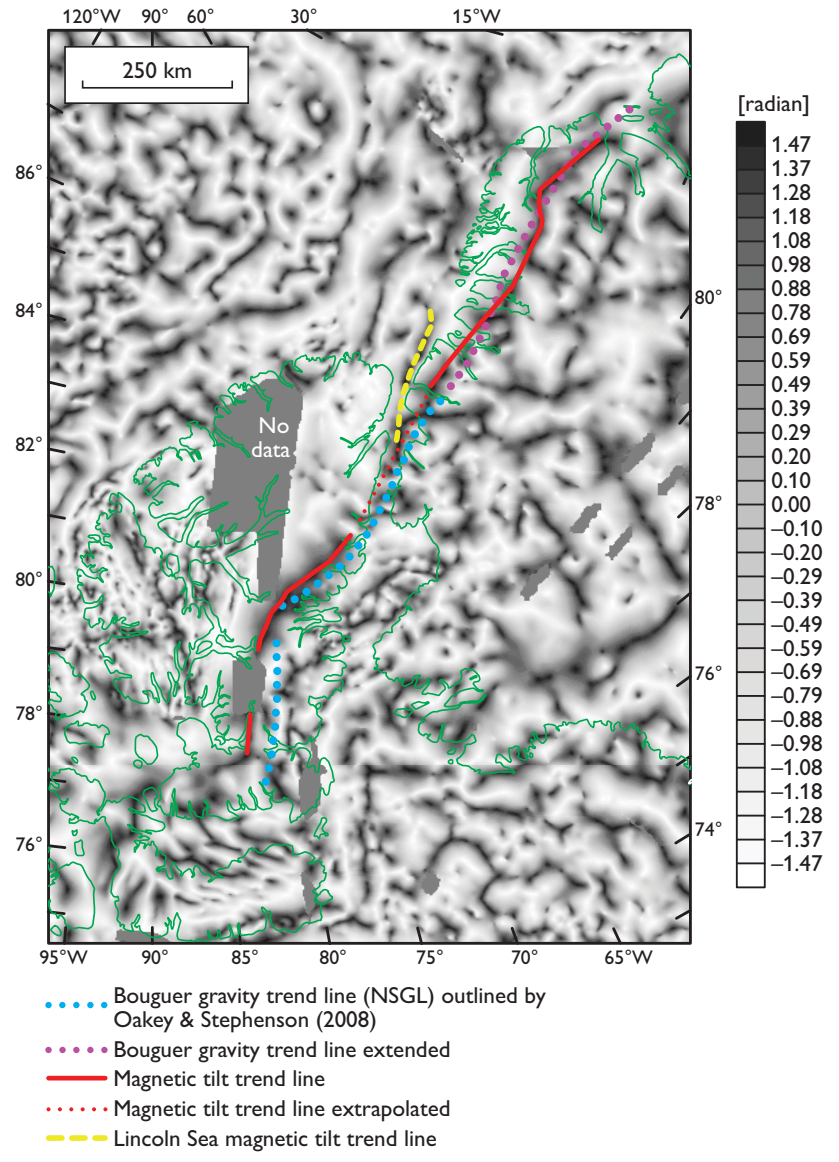

Fig. 4. Tilt-angle map derived from $5 \mathrm{~km}$ upward-continued, total magnetic field from data in Gaina et al. (2009).

and offshore on the total magnetic field map of Damaske \& Oakey (2006, fig. 5) including responses from volcanogenic sandstones. Depiction of these unconnected structures as a single anomaly is simply due to the above-mentioned lowpass filter properties of the applied upwards continuation.

Oakey \& Stephenson (2008) regard the NSGL to be an expression of low-density rocks within the Franklinian Basin and they demonstrate that the Palaeogene Eurekan frontal thrust (EFT) obliquely truncates it. Similarly, the magnetic trend is oblique to the EFT. We interpret the magnetic anomalies paralleling the NSGL to reflect the lateral contrast in magnetic properties between Franklinian Basin strata and the crystalline shield. The continuity of both the magnetic and gravimetric trends across Kennedy Channel in the vicinity of Hans $\varnothing$ implies that this area is not affected by a crustal dislocation.

Farther south at Smith Sound, E-W-trending, offshore, linear, magnetic anomalies represent dykes that correlate with Neoproterozoic basic dykes onshore (Oakey \& Damaske 2006). Correlation between several offshore and onshore dykes of Greenland is unequivocal, but on the oppos- 
ing coast, although potential correlatives occur, there is a narrow coastal gap between magnetically identified offshore dykes and those onland (Fig. 2; Dawes 2009, fig. 5; Pulvertaft \& Dawes 2011, fig. 3). We note here that on our magnetic tilt-angle map there is continuity in terms of texture of the magnetic tilt angle from the offshore area, intersected by dykes, to those onshore (Fig. 4).

\section{Conclusions}

A century after Frank Taylor's proposal, some two dozen geological-geophysical markers within Precambrian-Palaeozoic rocks have been identified that demonstrate stratigraphic and structural continuity across Nares Strait (Dawes \& Kerr 1982, pp. 369-386; Tessensohn et al. 2006, pp. 129160). The magnetic lineament brought to notice here represents one more marker that militates against plate-boundary strike-slip deformation through the seaway.

We take the persistence and parallelism of the magnetic and gravimetric anomalies to indicate crustal coherence between Greenland and Ellesmere Island and we conclude that these geophysical lineaments are incompatible with the Wegener Fault (Figs 1, 2). They confirm the story revealed by onshore outcrops that the Franklinian Basin is a structural entity stretching from Ellesmere Island to Greenland unhindered by a lithospheric break. We challenge advocates of the 100-year model to explain how a major dislocation can be reconciled with the geophysical lineaments, as well as other obstacles that cross the waterway, for example, the Neoproterozoic dyke swarm (Fig. 2). Furthermore, supporters of conventional reconstructions, such as those in Fig. 1, must explain the plate-tectonic mechanisms by which such features are repositioned into perfect alignment (without offset), how basic dykes can preserve their linearity (without deformation) and how the harmonious within-plate pattern of the regional geology is reassembled (without mismatch).

The Kennedy Channel geophysical lineaments - as well as two dozen previously defined markers - reflect intraplate geology that confirms the mythical character of the Wegener Fault which remains after a hundred years nothing more than a theory.

\section{References}

Cocks, L.R.M. \& Torsvik, T.H. 2006: European geography in a global context from the Vendian to the end of the Palaeozoic. Geological Society of London Memoir 32, 83-95.
Damaske, D. \& Oakey, G.N. 2006: Volcanogenic sandstones as aeromagnetic markers on Judge Daly Promontory and in Robeson Channel, northern Nares Strait. Polarforschung 74, 9-19.

Dawes, P.R. 2004: Explanatory notes to the Geological map of Greenland, 1:500 000, Humboldt Gletscher, Sheet 6. Geological Survey of Denmark and Greenland Map Series 1, 48 pp. + map.

Dawes, P.R. 2009: Precambrian-Palaeozoic geology of Smith Sound, Canada and Greenland: key constraint to palaeogeographic reconstructions of northern Laurentia and the North Atlantic. Terra Nova 21, 1-13.

Dawes, P.R. \& Kerr, J.W. (eds) 1982: Nares Strait and the drift of Greenland: a conflict in plate tectonics. Meddelelser om Grønland Geoscience 8, 392 pp.

Eide, E.A. (coord.) 2002: BATLAS - Mid Norway plate reconstruction atlas with global and Atlantic perspectives, 75 pp. Trondheim: Geological Survey of Norway.

Gaina, C., Werner, S.C. \& the CAMP-GM group 2009: Circum-Arctic Mapping Project - gravity and magnetic maps. Geological Survey of Norway, Report 2009.010, 21 pp.

Gaina, C., Werner, S.C., Mioara, M. \& the CAMP-GM group 2010: Magnetic and gravimetric anomaly maps of the Arctic, 1: 5000000. UNESCO and Geological Survey of Norway.

Hansen, K., Dawes, P.R., Frisch, T. \& Jensen, P.K. 2011: A fission track transect across Nares Strait (Canada-Greenland): further evidence that the Wegener Fault is a myth. Canadian Journal of Earth Sciences 48, 819-840.

Harrison, J.C., Brent, T.A. \& Oakey, G.N. 2006: Bedrock geology of the Nares Strait region of Arctic Canada and Greenland, with explanatory text and GIS content. Geological Survey of Canada Open File 5278, 60 pp. + map.

Harrison, J.C., Dewing, K. \& Mayr, U. 2007: Geology of Hans Island and adjacent parts of Kennedy Channel, northwest Greenland (Kalaallit Nunaat) and northern Nunavut (Canada). Geological Survey of Canada Open File 5321, 33 pp. + map.

Jackson, H.R., Hannon, T., Neben, S., Piepjohn, K. \& Brent, T.[A.] 2006: Seismic reflection profiles from Kane to Hall Basin, Nares Strait: evidence for faulting. Polarforschung 74, 21-39.

Mayr, U. (ed.) 2008: Geology of northeast Ellesmere Island adjacent to Kane Basin and Kennedy Channel, Nunavut. Geological Survey of Canada Bulletin 592, 404 pp.

Miller, H.G. \& Singh, V. 1994: Potential field tilt - a new concept for location of potential field sources. Journal of Applied Geophysics 32, 213-217.

Oakey, G.N. \& Damaske, D. 2006: Continuity of basement structures and dyke swarms in the Kane Basin region of central Nares Strait constrained by aeromagnetic data. Polarforschung 74, 51-62.

Oakey, G.N. \& Stephenson, R. 2008: Crustal structure of the Innuitian region of Arctic Canada and Greenland from gravity modelling: implications for the Palaeogene Eurekan orogen. Geophysical Journal International 173, 1039-1063.

Pulvertaft, T.C.R. \& Dawes, P.R. 2011: North Atlantic spreading axes terminate in the continental cul-de-sacs of Baffin Bay and the Laptev Sea. Canadian Journal of Earth Sciences 48, 593-601.

Taylor, F.B. 1910: Bearing on Tertiary mountain belts and on the origin of the Earth's plan. Bulletin of the Geological Society of America 21, 179226.

Tessensohn, F., Jackson, H.R. \& Reid, I.D. (eds) 2006: Nares Strait and Wegener transform fault. Polarforschung 74, $198 \mathrm{pp}$.

UNESCO 2010: Geological map of the World, scale 1:25 000 000, 3rd edition.

Wilson, J.T. 1963: Hypothesis of Earth's behaviour. Nature 198, 925-929. 